\title{
Time-Varying Co-Movement and Volatility Transmission between the Oil Price and Stock Markets in the Baltics and Four European Countries
}

\author{
Murad A. Bein \\ Cyprus International University \\ Lefkosa, North Cyprus, via Mersin 10, Turkey \\ E-mail.mbein@ciu.edu.tr \\ cross $^{\text {ref }}$ http://dx.doi.org/10.5755/j01.ee.28.5.17383
}

\begin{abstract}
The paper explores time-varying co-movement and volatility transmission between three Baltic (Estonia, Latvia and Lithuania) stock markets and two international crude oil indices (Brent and West Texas Intermediate (WTI)). It also investigates the relation between two major oil-importing (the EU and the UK) and oil-exporting (Norway and Russia) European countries and the two oil indices. We use daily data from 3 January 2000 to 18 January 2016. The DCCGARCH model was employed to account for the time-varying in this study, which yielded several important findings. We found that the Baltics have a positive albeit lower level of time-varying co-movement with the international oil markets. In addition, the results revealed that the impacts of oil shocks in the Baltics are also lower than in the other four European markets. However, this finding is contrary to the existing literature, which argues that the Baltics are integrated. Considering the time-varying and volatility transmission with the oil-importing and oil-exporting countries, we found that there exists high-level time-varying co-movement. We also found that the volatility transmission and the magnitude of shocks from the oil markets are higher in oil-exporting countries. This result has important implications, especially for international investors and oil companies seeking to benefit from risk diversification and hedging techniques.
\end{abstract}

Keywords: Oil Price, Volatility Transmission, Stock Return, Oil Shock, Dynamic Conditional, Baltic Stock Markets.

\section{Introduction}

After several rounds of meetings, the Organization of the Petroleum Exporting Countries (OPEC) reached an agreement to reduce output between 32.5 to 33 million barrels per day from a near record 33.8 million, which resulted in the crude oil price instantly increasing by $8 \%$ (Farchy \& Wigglesworth, 2016). The agreement will be effective from 1 January 2017. However, some analysts are pessimistic regarding the deal and argue that the agreement will allow OPEC members to avoid their commitments. Further, there exists major political differences between the largest oil producers such as Saudi Arabia and other key oil producers such as Iran and Iraq; therefore, the agreement may not be respected. Besides, there were previously a number of unsuccessful meetings between OPEC members, which shows that a clear difference in outlook exists between the members. Indeed, the countries most affected by the ongoing crude oil volatility are the oil-exporting countries, whether they are OPEC members or not. In this regard, Norway, the highest oil producer in Western Europe, has revealed that its investment in 2017 is expected to decline by $13 \%$ when compared to last year and $34 \%$ when compared to 2014 . Yet, a higher oil price means a higher production cost, which will ultimately be passed on to households, especially in non-oil-exporting countries (Backus \& Crucini, 2000). Nonetheless, the existing literature stresses that, due to financial integration, it is possible for the volatility to spill over from one market into other markets. Several authors have argued that financial integration actually increases the volatility among countries (Levine, 1997; Kaminsky \& Reinhart, 1999;
Kose et al., 2006). Therefore, one would expect the volatility of the oil market to spill over into other markets.

Given the importance of studying the relationship between stock returns and the oil markets, several researchers have explored the issue by employing different methods and data frequencies for different countries (Cong et al., 2008; Park \& Ratti, 2008; Miller \& Ratti, 2009; Chen et al., 2010; Arouri et al., 2011; Filis et al., 2011; Kiran, 2011; Masih et al., 2011; Wang et al., 2013; Fang \& You, 2014; Ghosh \& Kanjilal, 2014; Zhu, 2014; Avdulaj \& Barunik, 2015; Kang et al., 2015; Bein \& Aga, 2016; Ghosh \& Kanjilal, 2016). Among these studies is the paper by Miller \& Ratti (2009), which made use of monthly data for six Organisation for Economic Co-operation and Development (OECD) countries and employed a cointegrated vector error correction model, reported that the stock market responded negatively to the increase in the oil price during January 1971 to May 1980 and February 1988 to September 1999 However, they reported that after September 1999 the negative relationship began to disappear. Chen (2010), who used the time-varying transition-probability Markov-switching model, argued that a higher oil price causes the stock market to turn into a bear market. Kang et al. (2015) investigated the relationship between oil price shocks and the US return, and they argued that a demand shock in the oil market is associated with negative effects on the stock return and volatility, whereas oil supply disruptions are associated with positive effects on the stock return and volatility. Cong et al. (2008) explored the relationship between Chinese stock market indices and price shocks using multivariate vector auto-regression, and they found that an 
oil price shock does not affect the stock return for most Chinese stock indices. Although the above-mentioned researchers conducted studies in different countries, including both advanced economies and emerging economies, none of them investigated the relation between the Baltic stock markets and the international oil price. Some researchers have examined the advanced European markets. For instance, Park and Ratti (2008) investigated the relation for 13 developed European countries and the USA using a variance decomposition analysis, and they found that an oil price increase positively affects the Norwegian stock market. This is in line with the findings of Bein and Aga (2016), who investigated the Nordic countries and found that the global financial crisis changed the pattern of the relationship between the oil price and the stock price.

A reasonable number of studies have been conducted regarding the volatility and correlation between the Baltic stock markets and other European stock markets (Maneschiold, 2006; Nilsson, 2007; Soultanaeva, 2008; Aktan et al., 2010; Dubinskas \& Stunguriene, 2010; Masood et al., 2010; Brannas \& Soultanaeva, 2011; Alekneviciene et al., 2012; Brannas et al., 2012; Nikkinen et al., 2012; Babalos et al., 2016; Deltuvaite, 2016a; Deltuvaite, 2016b). Among these studies, Nikkinen et al. (2012) found that the integration between the three Baltic stock markets and the other European stock markets increased during the global financial crisis. In line with this finding, Brannas and Soultanaeva (2011) investigated reports from the USA and Russia concerning the three Baltic stock markets and found that US news had a greater impact than Russian news on the return of Estonia, while the Lithuanian market experienced a greater impact from Russian shocks. Interestingly, they documented no spillover from either the USA or Russia into the Latvian market. Deltuvaite (2016b) noted that the Baltic markets are integrated, as well as documenting that Lithuania and Estonia are strongly integrated when compared to Latvia. Yet, Alexakis et al. (2016) identified spillover during the global financial crisis into the Latvian and Lithuanian stock markets but not the Estonian market. However, during the European debt crisis, the Baltic markets were affected. Some authors investigated the Baltic stock markets by including other European markets, for example, Levisauskaite et al. (2014) studied the co-movement between bonds and stocks for 52 market indices, while Pilinkus and Boguslauskas (2009) studied the relationship between the Lithuanian stock price and macroeconomic variables.

This study is motivated by two principal factors. First, the existing literature reveals the Baltic stock markets to be integrated with the rest of the world markets. Therefore, it is necessary to investigate whether international oil price volatility directly or indirectly affects the three Baltic stock markets. It is worth noting that previous studies have documented how oil-importing countries are affected by oil volatility (Basher \& Sadorsky, 2006; Dhaoui \& Khraief 2014; Bouri, 2015). However, to the best of our knowledge, no previous study has examined the relationship between the Baltic stock markets and the international oil market. Second, oil price volatility may also affect the oil refineries that operate inside and outside the Baltics. The low oil price may force refineries to postpone their projected investment, as well as pushing them to renegotiate terms with both suppliers and creditors, which will ultimately affect the companies' share price.

Hence, this paper aims to analyse the time-varying relation and volatility transmission between the three Baltic stock returns (Lithuania, Estonia and Latvia) and two intentional oil price indices (Brent and West Texas Intermediate (WTI)) using a daily data that includes the period prior to the EU accession and ends after the last price shock during the first quarter of 2016. Further, the paper investigates the relation between two major oilimporting (the EU and the UK) and oil-exporting (Norway and Russia) countries and the two oil indices in order to compare whether the impacts are greater on oil-exporting countries than on the Baltics and the major oil-importing countries. Studying the time-varying and volatility transmission is important for the purposes of asset allocation and financial risk management, as well as formulation of fiscal and monetary policies (Kaminsky \& Reinhardt, 1999; Forbes \& Rigobon, 2002). A multivariate generalised autoregressive conditional heteroscedasticity (GARCH) framework is used to study the volatility spillovers between each country and the two international crude oil indices during the period 3 January 2000 to 18 January 2016. To account for the time variability of the conditional correlations, a dynamic structure is included via the use of Engle's (2002) dynamic conditional correlation (DCC) model.

The research undertaken in the article resulted in several important findings. First, we found that the Baltic stock markets have a positive albeit lower level of comovement, as well as lower volatility transmission than the other markets included in our study. Further, the impact of an oil shock is lower in the Baltic markets, with Latvia being completely isolated from any shocks and crashes in the oil market. Second, we showed that the Baltic stock markets have a higher return, with Estonia having the highest return, while all the Baltic stock markets have lower risk when compared to the other European stock markets. Further, the volatility transmission and oil shocks are higher with the oil-exporting countries (Norway and Russia) than with the EU and the UK. Additionally, the level of co-movement is slightly lower for the oilimporting countries. It is also worth noting that the comovement for the EU, the UK, Norway and Russia was initially negative, before changing to positive for Norway and Russia in 2005 and for the EU and the UK in 2008.

The remainder of the paper is organised as follows. Section two discusses the data and methodology, while section three presents the empirical results. Section four concludes the study and highlights the impacts of the research.

\section{Brief Financial, Economic and Energy Overview the Baltic States}

Table 1 presents the financial, macroeconomic and energy indictors for the Baltic states using three-year averaging for the period 2000 to 2014. In general, the Estonian stock market exhibited higher financial indictors than the other two Baltic markets. In particular, the stock market capitalisation to GDP (\%) (MC), stock market total 
value traded to GDP (\%) (SMTV), foreign direct investment net inflows (\% of GDP) (FDI), and gross portfolio equity assets to GDP (\%) were all higher for Estonia, which may explain why the Estonian market was more resilient at the beginning of the global financial crisis than the markets of the other Baltic states. During the period 2004 to 2006, there was an increase in the FDI in all three Baltic states due to their EU membership creating a positive atmosphere for investment. In terms of the 2007 to 2009 period, there was a general decline in all the financial indicators for all three countries. However, the decline was much more evident for the Estonian market, which the existing literature attributes to the effects of the European sovereign debt crisis (ESDC) (Alexakis et al., 2016). During the last six years, Estonia witnessed capital outflow, while Latvia and Lithuania experienced capital flow into their stock markets, although it is worth noting that during the global financial crisis these two countries also experienced outflow. In terms of the macroeconomic outlook, Latvia exhibited the lowest trade dependence, as well as having a slightly higher annual GDP than the other two countries. Both the inflation and merchandise exports to high-income economies are lower for Lithuania than for the other countries. In short, the Baltic markets can provide significant opportunities, since they are characterised by a moderate inflation rate and steady economic growth both before and after the global financial crisis (GFC) and ESDC, in addition to exhibiting financial openness.

A recent report by the European Commission (2017) revealed Russia to be the largest supplier of crude oil to the EU. In 2014, Russia was estimated to supply $30.4 \%$ of crude oil to the EU, while Norway was the second largest supplier to the EU, accounting for $13.1 \%$ of crude oil imports. Therefore, a total of $43.5 \%$ of the EU-28 crude oil imports came from Russia and Norway in 2014. In addition, the dependence on crude oil within the EU represents $88.2 \%$ of the total energy dependence. Further, Workman (2017) recently noted that the value of Russia's total crude oil exports during 2015 was estimated to be $\$ 86.2$ billion (accounting for $11 \%$ of the total value of crude oil exports), while the figure for Norway during the same year was $\$ 25.7$ billion (accounting for $3 \%$ of the total value of crude oil exports). Indeed, oil is a key input product within the EU and hence European countries are heavily reliant on it in order to meet their energy needs. Thus, Table 1 shows the energy dependence, final energy consumption by sector and energy intensity of the economy for the three Baltic states. The energy dependence demonstrates the extent to which an economy relies on imports to meet its energy needs. The lowest dependence can be seen in the case of Estonia, where the dependence reduced from 31.37 (2000-2002) to 12.6 (2012-2014), while Lithuania can be seen to increasingly rely on energy imports. The next column shows the final energy consumption by sector and it can be seen that Lithuania's sector (transport, household, services, agriculture, etc.) consumption of energy is higher than that of the other Baltic states. The final column shows the energy intensity of the economy, which measures the energy consumption and efficiency of an economy. Table 1 shows the highest sector consumption of energy to be observed in the case of Estonia. This is because the country possesses oil shale resources and is thus involved in exporting oil shale. For example, during 2012, an estimated 18.7 million tons of oil shale was produced, with almost $80 \%$ of this production being exported (Energy Regulators Region Association 2013). Examples of the energy companies that operate in Estonia include Eesti Energia, VKG Oil AS and Kiviõli Keemiatoostus OÜ. These companies also have international linkages. For instance, Eesti Energia has several subsidiaries that operate internationally, including Enefit American Oil. Further, the company makes substantial international investments. For example, it has invested an estimated $€ 25$ million in a Jordanian oil shale power plant and extraction project (Vahtla 2017). Similarly, VKG Oil AS, the largest Estonian oil company, has entered into a joint venture established by Royal Vopak and Global Ports to transport liquid fuels from Eastern Europe to Western Europe, America and South East Asia (Vopak E.O.S. n.d.). Additionally, companies listed in Lithuania that can also be affected by the global oil price include Klaipedos Nafta AB, Energijos Skirstymo, Lietuvos Energijos and Kauno Energija AB. There are also subsidiary companies that operate within the Baltics, for example, the Russian-owned Lukoil energy company operates Lukoil Baltija (Lukoil Baltija 2011), while the foreign-owned Orlen Lietuva announced that its 2016 profits had declined from 238 million USD in previous years to 237 million USD (Bloomberg 2017). Further, Gazprom, which is one of the largest Russian-owned oil companies, has invested in Latvijas Gaze, which is listed on the Latvian stock exchange ${ }^{1}$. Therefore, changes in the oil price directly affect the Baltic states both through individual energy companies and their overall national economies. For example, at the beginning of 2016, VKG Oil AS announced that it would have to lay off 500 workers due to the low oil price (Krjukov \& Rajavee, 2016). For this reason, it is necessary to investigate the relations between the three Baltic states and the global oil price.

\section{Data and Methodology}

\section{Data and Descriptive Statistics}

The study considers the major indices that are widely used by researchers. Hence, for the three Baltic countries, the chosen stock indices are TALLINN for Estonia, RIGA for Latvia and VILNIUS for Lithuania. The major oilexporting countries are represented by the OSLO EXCHANGE ALL SHARE for Norway and RTS for Russia. Since the European Union is the largest oil importer, we considered the EUROSTOXX50 stock price index, which represents 50 blue chip corporations from 11 Eurozone countries. It will be referred to as the EU index for the remainder of the article. The United Kingdom is represented by the FTSE 100 and it is included in this study due to the country being one of the major European oil importer. As a proxy for the global oil price level, two major indices are considered, namely Brent and West Texas Intermediate (WTI). Although the two indices are

\footnotetext{
${ }^{1}$ Russian corporations have also invested in LatRosTrans Ltd that operates in Latvia Liuhto and Jumpponen (2002).
} 
used as benchmarks, Brent is more widely used because the prices generated using the Brent complex constitute the main price benchmarks on the basis of which $70 \%$ of the international trade in oil is directly or indirectly priced (Fatouh, 2011). In addition, Fatouh (2011) showed that Europe imports its crude oil based on the Brent benchmarks, since Brent is overseen by the UK government and it has a robust legal regime. Indeed, both companies and traders use Brent to price cargoes under long-term contracts or in spot market transactions, while futures exchanges use Brent for the settlement of their financial contracts, and banks and companies use Brent for the settlement of derivative instruments such as swap contracts. This approach is also in line with the existing literature, which suggests that Brent pricing represents the largest world oil production pricing (Antonakakis \& Filis, 2013). Further, several authors who have investigated the relationship between stock markets and the oil price made use of Brent (Park \& Ratti, 2008; Filis, 2011; Guesmi \& Fattoum, 2014). WTI is the main benchmark used for pricing oil imports into the USA, but few researchers have employed it (Sadorsky, 2012), although some studies did use both indices (Arouri et al., 2010). We make use of daily data from 3 January 2000 to 18 January 2016. Our sample study considers a longer period than most prior studies in order to observe the long-term relationship between the crude oil market and the chosen stock indices. All the data are obtained from the Thomson Reuters DataStream. Table 2 presents descriptive statistics concerning the seven stock market indices and the two oil market indices. Looking at the mean in the first column of Table 2, it can be seen that the highest positive returns are observed in the three Baltic markets, with the highest being the Estonian stock return (4.4\%), followed by the Latvian return $(4.2 \%)$.

Additionally, a negative return is observed for the EU $(1.2 \%)$ and the UK $(0.4 \%)$. The next column presents the indices' standard deviations and it can be observed that the Russian stock market is the most risky market, followed by the oil indices. Almost all the return series exhibit negative skewness, except for Estonia and the EU, where the positive skewness and kurtosis are above 6 , which reflects the stylised characteristics of the financial series. The LjungBox Q statistics and the Q statistics on the standardised squared residuals at the lag (20) indicate the presence of autoregressive conditional heteroskedasticity (ARCH) effects, which is confirmed by the significant ARCH tests. The augmented Dickey-Fuller (ADF) test results concerning the return series reject the null value of the unit root of the return series. The returns are obtained by first transforming the level data into logarithmic data and then taking the first difference and multiplying it by 100 . Table 3 shows a correlation between Brent and WTI using both Spearman's rho and Kendall's tau-b. It can also be observed that Norway and Russia (i.e., oil-exporting countries) exhibit a higher correlation using both methods, followed by the EU and the UK (i.e., two more developed economies). However, the Baltics exhibit lower correlation, with the lowest correlation being seen for Latvia.

Financial, Economic and Energy Overview of the Baltic States

Table 1

\begin{tabular}{|c|c|c|c|c|c|c|c|c|c|c|c|c|c|}
\hline \multirow[b]{2}{*}{ Year } & \multicolumn{6}{|c|}{ Financial indictors } & \multicolumn{4}{|c|}{ Macroeconomic indictors } & \multicolumn{3}{|c|}{ Energy indictors } \\
\hline & MC & SMT & SMTR & NLC & FDI & PQ & Trade & GG & INF & ME & ED & FEC & EIE \\
\hline \multicolumn{14}{|l|}{ Estonia } \\
\hline 1 & 28 & 4 & 15 & 12 & 7 & 0.4 & 126 & 8 & 4 & 92 & 31.37 & 2576 & 447 \\
\hline 3 & 25 & 8 & 24 & 13 & 12 & 9.6 & 137 & 4 & 7 & 88 & 26.20 & 3016 & 343 \\
\hline 4 & 11 & 2 & 14 & 12 & 11 & 9.6 & 131 & 7 & 3 & 91 & 15.87 & 2836 & 393 \\
\hline 5 & 8 & 1 & 9 & 12 & 12 & 12.1 & 133 & 6 & 2 & 91 & 12.60 & 2889 & 380 \\
\hline \multicolumn{14}{|l|}{ Latvia } \\
\hline 1 & 7.0 & 2.1 & 30.8 & 26.8 & 2.6 & 0.5 & 83.8 & 6.3 & 2.4 & 90.8 & 59.67 & 3482 & 309 \\
\hline 2 & 10.6 & 1.1 & 9.1 & 20.6 & 3.9 & 0.7 & 93.1 & 9.2 & 5.3 & 92.0 & 65.50 & 3907 & 271 \\
\hline 3 & 10.5 & 0.4 & 3.5 & 17.6 & 6.9 & 1.5 & 96.2 & 6.1 & 10.7 & 91.4 & 62.67 & 4234 & 223 \\
\hline 4 & 5.7 & 0.1 & 2.4 & 15.6 & 4.5 & 3.8 & 91.0 & 7.2 & 2.3 & 91.4 & 55.27 & 4010 & 245 \\
\hline 5 & 3.7 & 0.1 & 3.0 & 15.2 & 5.1 & 5.3 & 93.4 & 7.5 & 0.9 & 91.6 & 50.97 & 4050 & 247 \\
\hline \multicolumn{14}{|c|}{ Lithuania } \\
\hline 1 & 11.1 & 1.8 & 14.3 & 13.8 & 3.8 & 0.1 & 92.4 & 5.7 & 0.9 & 88.8 & 49.07 & 3925 & 406 \\
\hline 2 & 21.7 & 1.7 & 8.9 & 13.0 & 2.6 & 0.3 & 105.0 & 8.3 & 0.9 & 89.9 & 49.07 & 4429 & 366 \\
\hline 4 & 12.0 & 0.8 & 6.1 & 12.0 & 4.0 & 4.0 & 105.9 & 7.0 & 3.3 & 88.5 & 71.13 & 4753 & 262 \\
\hline 5 & 9.2 & 0.5 & 4.4 & 11.0 & 4.1 & 4.5 & 110.5 & 7.4 & 1.4 & 88.5 & 78.87 & 4759 & 307 \\
\hline
\end{tabular}

Note. We reported three-year averaging for the periods 2000-2002 (1), 2003-2005 (2), 2006-2008 (3), 2009-2011 (4), and 2012-2014 (5). Abbreviations: stock market capitalisation to GDP (\%) (MC), stock market total value traded to GDP (\%) (SMT), stock market turnover ratio (\%) (SMTR), number of listed companies per 1,000,000 people (NLC), foreign direct investment net inflows (\% of GDP) (FDI), gross portfolio equity assets to GDP (\%) (PQ), trade (\% of GDP) (Trade), GDP growth (annual \%) (GG), inflation (INF), merchandise exports to high-income economies (\% of total merchandise exports) (ME), energy dependence (ED), final energy consumption by sector (FEC), and energy intensity of the economy (EIE). Data for MC, SMT and SMTR ends in 2012. Source: European Commission (2017) and World Bank (2017). 
Table 2

Descriptive Statistics

\begin{tabular}{|c|c|c|c|c|c|c|c|c|}
\hline Name & Mean & Std. Dev. & Skewness & Kurtosis & ARCH (5) & $Q(20)$ & Q2(20) & ADF \\
\hline BRENT & 0.002 & 2.183 & -0.126 & 6.792 & $50.7 \mathrm{a}$ & $38.8 \mathrm{a}$ & $1167 \mathrm{a}$ & $-36 a$ \\
\hline WTI & 0.003 & 2.417 & -0.225 & 7.518 & $93.3 \mathrm{a}$ & $41.2 \mathrm{a}$ & $1889 a$ & $-36 a$ \\
\hline EST & 0.044 & 1.109 & 0.131 & 12.099 & $62.2 \mathrm{a}$ & $168 \mathrm{a}$ & $977 \mathrm{a}$ & $-33 a$ \\
\hline LVA & 0.042 & 1.439 & -0.454 & 19.694 & $280 \mathrm{a}$ & $211 \mathrm{a}$ & $5185 a$ & $-33 a$ \\
\hline LTU & 0.038 & 1.083 & -0.532 & 30.290 & $142 \mathrm{a}$ & $259 a$ & $1400 \mathrm{a}$ & $-34 a$ \\
\hline $\mathrm{NO}$ & 0.027 & 1.393 & -0.610 & 9.374 & $285 a$ & $42.6 \mathrm{a}$ & $7330 a$ & $-38 \mathrm{a}$ \\
\hline RU & 0.031 & 4.406 & -2.350 & 1178.7 & $407 a$ & $625 a$ & $1034 a$ & $-45 a$ \\
\hline EU & -0.012 & 1.507 & 0.003 & 7.312 & $162 \mathrm{a}$ & $70 \mathrm{a}$ & $3436 a$ & $-41 \mathrm{a}$ \\
\hline UK & -0.004 & 1.210 & -0.160 & 9.335 & $229 a$ & $97 \mathrm{a}$ & $469 a$ & $-42 \mathrm{a}$ \\
\hline
\end{tabular}

Note: EST (Estonia), LVA (Latvia), LTU (Lithuania), NO (Norway), and RU (Russia). a, b and c are statistically significant at $1 \%$, $5 \%$ and $10 \%$, respectively.

Correlations Using Two Techniques

Table 3

\begin{tabular}{|c|c|c|c|c|}
\hline & \multicolumn{2}{|c|}{ Spearman's rho } & \multicolumn{2}{c|}{ Kendall's tau-b } \\
\hline Name & BRENT & WTI & BRENT & WTI \\
\hline EST & $.094 \mathrm{a}$ & $.071 \mathrm{a}$ & $.064 \mathrm{a}$ & $.048 \mathrm{a}$ \\
\hline LVA & $.039 \mathrm{a}$ & 0.023 & $.026 \mathrm{~b}$ & .016 \\
\hline LTU & $.083 \mathrm{a}$ & $.069 \mathrm{a}$ & $.232 \mathrm{a}$ & $.046 \mathrm{a}$ \\
\hline NO & $.335 \mathrm{a}$ & $.254 \mathrm{a}$ & $.183 \mathrm{a}$ & $.174 \mathrm{a}$ \\
\hline RU & $.264 \mathrm{a}$ & $.199 \mathrm{a}$ & $.116 \mathrm{a}$ & $.137 \mathrm{a}$ \\
\hline EU & $.170 \mathrm{a}$ & $.161 \mathrm{a}$ & $.143 \mathrm{a}$ & $.110 \mathrm{a}$ \\
\hline UK & $.208 \mathrm{a}$ & $.187 \mathrm{a}$ & $128 \mathrm{a}$ \\
\hline
\end{tabular}

Note: $a, b$ and c are statistically significant at $1 \%, 5 \%$ and $10 \%$, respectively.

\section{Methodology}

The GARCH family has been employed by several authors when measuring spillover effects and modelling financial assets (Ahmed at al., 2016; Vveinhardt et al., 2016). In recent years, in order to account for heteroscedasticity, endogeneity and omitted variable bias, researchers have employed several advanced techniques, including the rolling wavelet, dynamic copulas with and without regime-switching, and dynamic conditional correlation (DCC) models. Some researchers also make use of one of the above methods to study co-movement among the assets (Aloui et al., 2011; Dajcman \& Kavkler, 2011). In this study, we make use of the multivariate DCCGARCH model formulated by Engle (2002). This model has advantages over the other models, since it allows for the detection of possible changes in conditional correlations over time, which is very important given that time series data exhibits time-varying behaviour (Syllignakis \& Kouretas, 2011; Harkmann, 2014; Bein \& Gulcay, 2016). In estimating Engle's (2002) DCC model, the first step is to estimate a univariate GARCH-type model for each stock index and crude oil market. Then, it is necessary to estimate the conditional correlations that vary over time. The DDC model of Engle (2002) can be expressed as:

$$
\boldsymbol{L}_{t}=\boldsymbol{G}_{t} \boldsymbol{E}_{t} \boldsymbol{G}_{t}
$$

where $L_{t}$ is the conditional covariance matrix, which is decomposed into conditional standard deviations, $G_{t}=\operatorname{diag}\left(L_{1,1, t}^{1 / 2}, \ldots . ., L_{N, N, t}^{1 / 2}\right)$, in which $\boldsymbol{L}_{i, i, t}$ is any univariate $\mathrm{GARCH}$ process, and $E_{t}$ is the time-dependent conditional correlations matrix, which can be specified as: $E_{t}=\operatorname{diag}\left(y_{11, t}^{-1 / 2}, \ldots ., y_{N N, t}^{-1 / 2}\right) \bar{Y}_{t}\left(y_{11, t}^{-1 / 2}, \ldots ., y_{N N, t}^{-1 / 2}\right)$ where $Y_{t}$ is a symmetric positive definite matrix for the dynamic correlation structure expressed as:

$$
Y_{t}=(1-a-b) \bar{Y}+a n_{t-1} n_{t-1}^{\prime}+b Y_{t-1}
$$

where $n_{t}$ is a vector of the standardised residuals, $\bar{Y}$ is unconditional variance matrix of $n_{t}$ and $a$ and $b$ are non-negative autoregressive and variance coefficients that meet the condition $a+b<1$. In the final step, the DCC is estimated using the following equation:

$$
p_{l z_{z} t}=\frac{q l_{z, t}}{\sqrt{q u l t} q_{z z_{i} t}}
$$

where $p_{l z_{t} t}$ is the DCC between the oil and stock indices ( 1 and $\mathrm{z}$ ). We utilised the quasi-maximum likelihood (QML) estimation method using Student's $t$ distribution. To investigate the impact of oil shocks on the stock returns, we estimated the following equations. The mean equations for the seven countries included in this study.

$$
\begin{aligned}
& r_{t}=\mu_{t}+\gamma_{1} r_{t-1}+\gamma_{2} r_{t-1} \text { Brent } W T I+\varepsilon_{t} \\
& \text { where } \\
& r_{t}=\left(r_{1, t}, r_{2, t}, \ldots, r_{n, t}\right)^{\prime}, \mathrm{n}=7 ; \varepsilon_{t}= \\
& \left(\varepsilon_{1, t}, \varepsilon_{2, t,}, \ldots \ldots \varepsilon_{n, t}\right)^{\prime} ; \varepsilon \mid \Omega_{t-1} \sim \mathrm{N}(0, \mathrm{Ht})
\end{aligned}
$$

To account for the presence of autocorrelation, we used autoregressive (AR (1)), while one-day lagged is used for Brent and WTI so as to account for the time difference between the international crude oil price and the seven stock price indices.

\section{Empirical Results}

Table 4 presents the results concerning the mean and variance from the GARCH and the DCC derived from the seven stock indices, with Brent and WTI in panel B and 
panel C, respectively. The lagged conditional volatility and shock-squared terms in the variance equation are significant, indicating that both past volatility and today's news are rapidly and immediately reflected in the indices' current value. This means that the current value of conditional volatility in the seven stock returns depends on past volatility and past unexpected shocks in the real equity return. Likewise, uncertainty in the oil price variables is reflected in the conditional volatility of the oil return. Looking at the derived DCC between panel B (Brent) and panel C (WTI) with each stock market, it is evident that a and $\mathrm{b}$ are non-negative and the condition $\mathrm{a}+\mathrm{b}<1$ is met. Additionally, Student's t-distribution is statistically significant in panels $\mathrm{B}$ and $\mathrm{C}$, which demonstrates the appropriateness of selecting the t-distribution when studying the relationship between two oil indices and seven stock indices. Further, the volatility transmission coefficients $a$ and $b$ between the two oil indices and the stock indices are highly significant for almost all the markets, except for the LVA market where a and $b$ are insignificant with WTI, while with Brent the a coefficient is not significant but the volatility coefficient $b$ is significant albeit with a lower magnitude, which indicates that there is a limited relationship between the LVA stock market and the oil indices during periods of both stability and turmoil. This reveals the existence of diversification benefit between the Latvian stock exchange and the global oil market. Further, Arouri et al. (2011) revealed that small economies can be isolated from global commodity market risks and information flow. This finding is line with the results of studies by Brannas and Soultanaeva (2011) and Deltuvaite (2016), who found that Latvia is less integrated., However, other studies have found that Latvia was intergraded during the global financial crisis (Nikkinen et al., 2012; Alexakis et al., 2016). In addition, higher volatility transmission is observed for the oil-exporting countries, with the highest magnitude revealing that these two countries are risky, since their economies depend on commodities exports, which are more sensitive to changes in the international price market. Hence, volatility in commodities is instantly reflected in their stock markets. Indeed, the low oil price hurt their economies, since it affected their revenues, which means there is less opportunity for asset allocation between Russia and Norway and the international oil market. These findings are in line with the observations of researchers who argue that oilexporting stock markets are highly volatile (Awartani \& Maghyereh, 2013; Wang et al., 2013). Additionally, in order to explore the opportunities offered by other countries, the time-varying relationship should be investigated, since it helps to explain the relationship between the oil price and individual stock markets. Further, we ran an autoregressive (AR)-GARCH for the seven stock indices by including the return of the international crude oil indices in the mean equation in order to observe whether impacts of the international oil price can be seen on each stock market. Table 5 illustrates the estimations from the multivariate DCC-GARCH estimation for the seven stock indices by including Brent in the mean equation. The impact of crude oil is demonstrated by $\gamma_{2}$ and the result shows that the international crude oil market has statistically significant impacts on most of the stock markets, except in the case of Latvia where the coefficient is insignificant. This finding supports the notion that Latvia is isolated from the rest of the markets. Further, the $\operatorname{AR}(1)$ coefficient $\left(\gamma_{1}\right)$ for all the markets is significant, albeit with mixed signs, with markets such as Norway, the EU, the UK and Lithuania having a negative sign, while Russia, Estonia and Latvia have a positive sign. This finding is in line with prior literature arguing that advanced markets have a negative $\operatorname{AR}(1)$ because of positive feedback in trading, while emerging markets have a positive $\mathrm{AR}(1)$ due to partial price adjustments (Antoniou et al., 2005; Chiang et al., 2007). In addition, estimating the $\mathrm{AR}(1)$ accounts for any autocorrelation in the model. The GARCH coefficients and generated multivariate data for all the markets are all statistically significant which is in line with the findings presented in Table 4. The results of the AR-GARCH between the WTI oil price and the seven stock markets are not reported, since the results were the same as those presented in Table 5, although they are available upon request.

Estimation Results of the GARCH(1,1) and the Derived DCC Equations

Table 4

\begin{tabular}{|c|c|c|c|c|c|c|c|c|}
\hline \multicolumn{9}{|c|}{ Panel B GARCH(1,1) estimation } \\
\hline & \multirow{2}{*}{\multicolumn{2}{|c|}{$\frac{\text { Mean Eq. }}{\mu}$}} & \multicolumn{6}{|c|}{ Variance Eq. } \\
\hline \multirow[b]{2}{*}{ EST } & & & \multicolumn{2}{|c|}{$\omega$} & \multicolumn{2}{|c|}{$\alpha$} & \multicolumn{2}{|c|}{$\beta$} \\
\hline & \multicolumn{2}{|r|}{$[0.013]$} & $0.016 \mathrm{a}$ & {$[0.006]$} & $0.142 \mathrm{a}$ & {$[0.025]$} & $0.863 \mathrm{a}$ & {$[0.022]$} \\
\hline LVA & $0.065 \mathrm{a}$ & {$[0.014]$} & $0.052 \mathrm{a}$ & {$[0.018]$} & $0.123 \mathrm{a}$ & [0.029] & $0.851 \mathrm{a}$ & {$[0.034]$} \\
\hline LTU & $0.056 \mathrm{a}$ & {$[0.014]$} & 0.017 & {$[0.016]$} & $0.109 \mathrm{a}$ & {$[0.042]$} & $0.890 \mathrm{a}$ & {$[0.055]$} \\
\hline NO & $0.086 \mathrm{a}$ & [0.016] & $0.034 \mathrm{a}$ & [0.008] & $0.109 \mathrm{a}$ & [0.015] & $0.872 \mathrm{a}$ & {$[0.017]$} \\
\hline RU & $0.132 \mathrm{a}$ & {$[0.034]$} & -0.001 & {$[0.042]$} & $0.132 \mathrm{a}$ & [0.033] & $0.920 \mathrm{a}$ & [0.013] \\
\hline DEU & $0.043 \mathrm{~b}$ & {$[0.018]$} & $0.024 \mathrm{a}$ & [0.007] & $0.089 \mathrm{a}$ & [0.013] & $0.901 \mathrm{a}$ & {$[0.014]$} \\
\hline DUK & $0.033 \mathrm{a}$ & {$[0.013]$} & $0.015 \mathrm{a}$ & [0.004] & $0.106 \mathrm{a}$ & {$[0.015]$} & $0.885 \mathrm{a}$ & {$[0.016]$} \\
\hline DBRENT & 0.025 & {$[0.027]$} & $0.012 \mathrm{~b}$ & {$[0.006]$} & $0.044 \mathrm{a}$ & {$[0.008]$} & $0.955 \mathrm{a}$ & {$[0.008]$} \\
\hline \multirow[t]{3}{*}{ DWTI } & 0.035 & {$[0.032]$} & $0.028 \mathrm{~b}$ & {$[0.014]$} & $0.050 \mathrm{a}$ & {$[0.012]$} & $0.946 \mathrm{a}$ & [0.012] \\
\hline & \multicolumn{6}{|c|}{ Panel B Multivariate DCC equations for each stock market with Brent } & & \\
\hline & EST & LVA & LTU & NO & $\mathrm{RU}$ & EU & UK & \\
\hline \multirow[t]{2}{*}{$\mathrm{a}$} & $0.012 \mathrm{a}$ & 0.008 & $0.016 \mathrm{a}$ & $0.014 \mathrm{a}$ & $0.020 \mathrm{a}$ & $0.025 \mathrm{a}$ & $0.023 \mathrm{a}$ & \\
\hline & [0.004] & {$[0.010]$} & {$[0.006]$} & {$[0.003]$} & {$[0.005]$} & {$[0.006]$} & {$[0.006]$} & \\
\hline \multirow[t]{2}{*}{$\mathrm{b}$} & $0.967 \mathrm{a}$ & $0.628 \mathrm{~b}$ & $0.963 \mathrm{a}$ & $0.985 \mathrm{a}$ & $0.976 \mathrm{a}$ & $0.970 \mathrm{a}$ & $0.973 \mathrm{a}$ & \\
\hline & {$[0.013]$} & {$[0.287]$} & {$[0.021]$} & {$[0.004]$} & {$[0.007]$} & {$[0.009]$} & {$[0.008]$} & \\
\hline \multirow[t]{2}{*}{$\mathrm{df}$} & $5.624 \mathrm{a}$ & $5.361 \mathrm{a}$ & $4.927 \mathrm{a}$ & $8.824 \mathrm{a}$ & $4.792 \mathrm{a}$ & $8.610 \mathrm{a}$ & $8.857 \mathrm{a}$ & \\
\hline & {$[0.279]$} & {$[0.256]$} & {$[0.211]$} & {$[0.737]$} & {$[0.218]$} & {$[0.701]$} & $\begin{array}{l}0.732] \\
\end{array}$ & \\
\hline
\end{tabular}




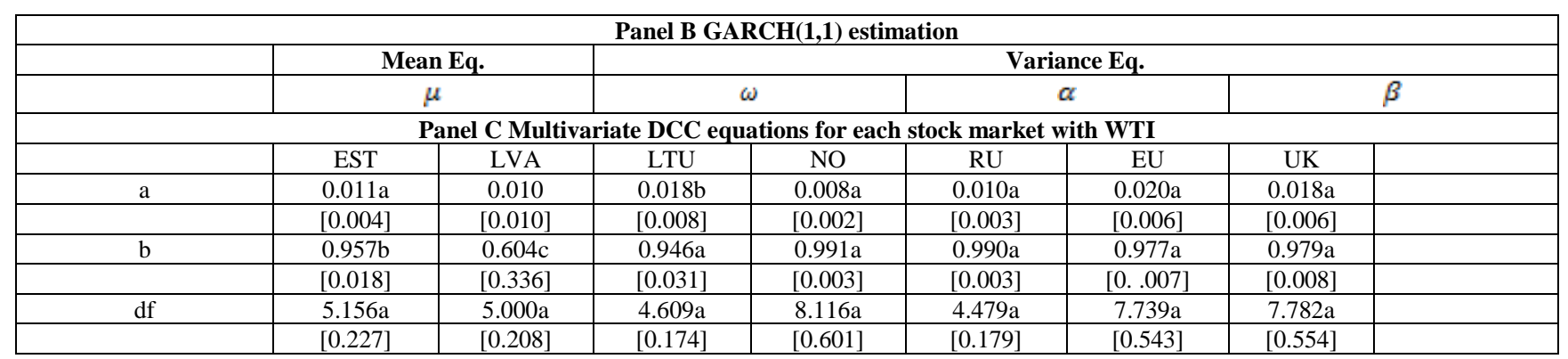

Note: The numbers given in [ ] are standard errors, while a, b and c are statistically significant at $1 \%, 5 \%$ and $10 \%$, respectively.

Table 5

Estimation Results from the DCC-GARCH Model

\begin{tabular}{|c|c|c|c|c|c|c|}
\hline & $\mu$ & $\gamma_{1}$ & $\gamma_{2}$ & $\omega$ & $\alpha$ & $\beta$ \\
\hline \multirow[t]{2}{*}{ EST } & $0.041 \mathrm{a}$ & $0.148 \mathrm{a}$ & $0.026 \mathrm{a}$ & $0.016 \mathrm{a}$ & $0.140 \mathrm{a}$ & $0.863 \mathrm{a}$ \\
\hline & {$[0.015]$} & {$[0.021]$} & {$[0.007]$} & {$[0.005]$} & {$[0.023]$} & {$[0.021]$} \\
\hline \multirow[t]{2}{*}{ LVA } & $0.063 \mathrm{a}$ & $-0.087 a$ & 0.012 & $0.052 \mathrm{a}$ & $0.124 \mathrm{a}$ & $0.850 \mathrm{a}$ \\
\hline & {$[0.013]$} & {$[0.020]$} & {$[0.010]$} & {$[0.019]$} & {$[0.030]$} & {$[0.034]$} \\
\hline \multirow[t]{2}{*}{ LTU } & $0.056 \mathrm{a}$ & $0.094 \mathrm{a}$ & $0.027 \mathrm{a}$ & $0.019 \mathrm{a}$ & $0.110 \mathrm{a}$ & $0.886 a$ \\
\hline & {$[0.015]$} & {$[0.024]$} & {$[0.008]$} & {$[0.018]$} & {$[0.043]$} & {$[0.058]$} \\
\hline \multirow[t]{2}{*}{$\mathrm{NO}$} & $0.075 \mathrm{a}$ & $-0.030 c$ & $0.162 \mathrm{a}$ & $0.035 \mathrm{a}$ & $0.113 \mathrm{a}$ & $0.866 \mathrm{a}$ \\
\hline & {$[0.015]$} & {$[0.017]$} & [0.011] & {$[0.008]$} & {$[0.014]$} & {$[0.015]$} \\
\hline \multirow[t]{2}{*}{ RU } & $0.083 \mathrm{~b}$ & $0.102 b$ & $0.281 \mathrm{a}$ & -0.015 & $0.139 \mathrm{a}$ & $0.919 \mathrm{a}$ \\
\hline & {$[0.042]$} & {$[0.045]$} & [0.039] & {$[0.043]$} & {$[0.037]$} & {$[0.011]$} \\
\hline \multirow[t]{2}{*}{$\mathrm{EU}$} & $0.038 \mathrm{~b}$ & $-0.046 a$ & $0.064 \mathrm{a}$ & $0.026 \mathrm{a}$ & $0.087 \mathrm{a}$ & $0.901 \mathrm{a}$ \\
\hline & {$[0.017]$} & {$[0.016]$} & {$[0.011]$} & {$[0.007]$} & {$[0.013]$} & {$[0.014]$} \\
\hline \multirow[t]{2}{*}{ UK } & $0.029 \mathrm{~b}$ & $-0.042 a$ & $0.073 \mathrm{a}$ & $0.016 \mathrm{a}$ & $0.106 \mathrm{a}$ & $0.884 \mathrm{a}$ \\
\hline & {$[0.012]$} & {$[0.016]$} & {$[0.008]$} & {$[0.004]$} & {$[0.015]$} & {$[0.016]$} \\
\hline \multicolumn{7}{|c|}{ Panel B Multivariate DCC equations between the seven stock markets with Brent } \\
\hline & & Coefficients & & Std. error & & $\mathrm{t}$-value \\
\hline $\mathrm{a}$ & & $0.0145 \mathrm{a}$ & & [0.0028] & & $(5.159)$ \\
\hline $\mathrm{b}$ & & $0.9647 \mathrm{a}$ & & {$[0.0100]$} & & $(96.81)$ \\
\hline df & & $5.8604 \mathrm{a}$ & & [0.2027] & & $(28.92)$ \\
\hline
\end{tabular}

Note: The numbers given in [ ] are standard errors, while those in ( ) are t-values. a, b and c are statistically significant at $1 \%, 5 \%$ and $10 \%$, respectively.

Figures 1 and 2 show the time-varying interrelationship between the two international oil indices and the major stock price indices. Figure 1 demonstrates the interrelationship between Brent and the seven stock indices. Looking at the co-movement of the three Baltics with Brent, it can be observed that the level of the time-varying relationship is not very high and, further, that all three have nearly identically co-movement with the oil markets. For example, the conditional correlations are very low for all three Baltics throughout the period, except for a brief increase seen for Estonia and Lithuania during the GFC of 2007-2009 and the ESDC of 2009-2012. ${ }^{2}$ It is also worth noting that during the ESDC, the increase was slightly higher for both countries, with the increase reaching $25 \%$ for Estonia and 30\% for Lithuania. Studying the time varying during the crisis has important implications, since an increase in the correlation will result in investors' appetites for risk falling during periods of turmoil and, consequently, the value of the firms will also fall. Forbes

\footnotetext{
2 The Federal Reserve Board of St. Louis (2009) has produced a timeline of the crisis, which shows that the GFC lasted from the beginning of 2007 to the first quarter of 2009. It is worth noting that the global financial crisis originated from the results of the subprime mortgage crisis spreading to other markets. However, the ESDC began on 19 October 2009, which was the date when the newly elected Greek Prime Minister, George Papandreou, disclosed that the public deficit was actually twice what had initially been estimated (Moya 2009). It lasted until December 2012, when the European Central Bank (2012) revealed a projection of economic growth during the 2013 .
}

and Rigobon (2002) defined a contagion as a short-term increase in the conditional correlation during a crisis period. Table 1 illustrates The effects of these crises on the Baltics stock markets falls during the crisis, which is in line with this finding. Considering the major oil-exporting countries, namely Russia and Norway, we observed that the correlation was negative and low. Yet, after 2005, a sharp increase in the correlation can be observed, reaching at its highest during GFC and ESDC. In addition, the two countries experienced a brief decline in 2014 in response to the oil supply glut, which was also the case for all the markets except for Latvia. Considering the major European oil-importing countries, namely the EU and the UK, it can be observed that the time-varying relationship was negative until the period prior to the oil shock of 2008, which caused the oil price to reach 145 USD per barrel. However, after that period, the time-varying relationship started to increase, reaching its highest level during the ESDC period and remaining there until the end of 2012, while in the following year it started to decline. In sum, this finding is in line with the existing literature, which suggests that the relationship between stock markets and the oil return responds to both aggregate demand shock (GFC and ESDC) and supply side shock (Guesmi \& Fattoum, 2014). Figure 2 illustrates the time-varying relationship between the seven indices and WTI. Again, the three Baltics exhibit a lower conditional correlation with WTI. For the oilexporting European countries, we observed that the time- 
varying relationship was negative and low, although starting from 2005 it began to increase. It remained high during the GFC and ESDC periods, before declining in response to the oil supply glut and then beginning to rise again. For the major oil-importing countries, negative time varying can be observed up to the start of the GFC, after which it remained high until the end of 2012 and then started to decline due to the oil supply glut. When comparing the effects on the major oil-exporting and oilimporting countries, it can be observed that the time varying is slightly higher for the oil-exporting countries. Additionally, during the GFC, the oil-exporting countries responded earlier to the crisis.

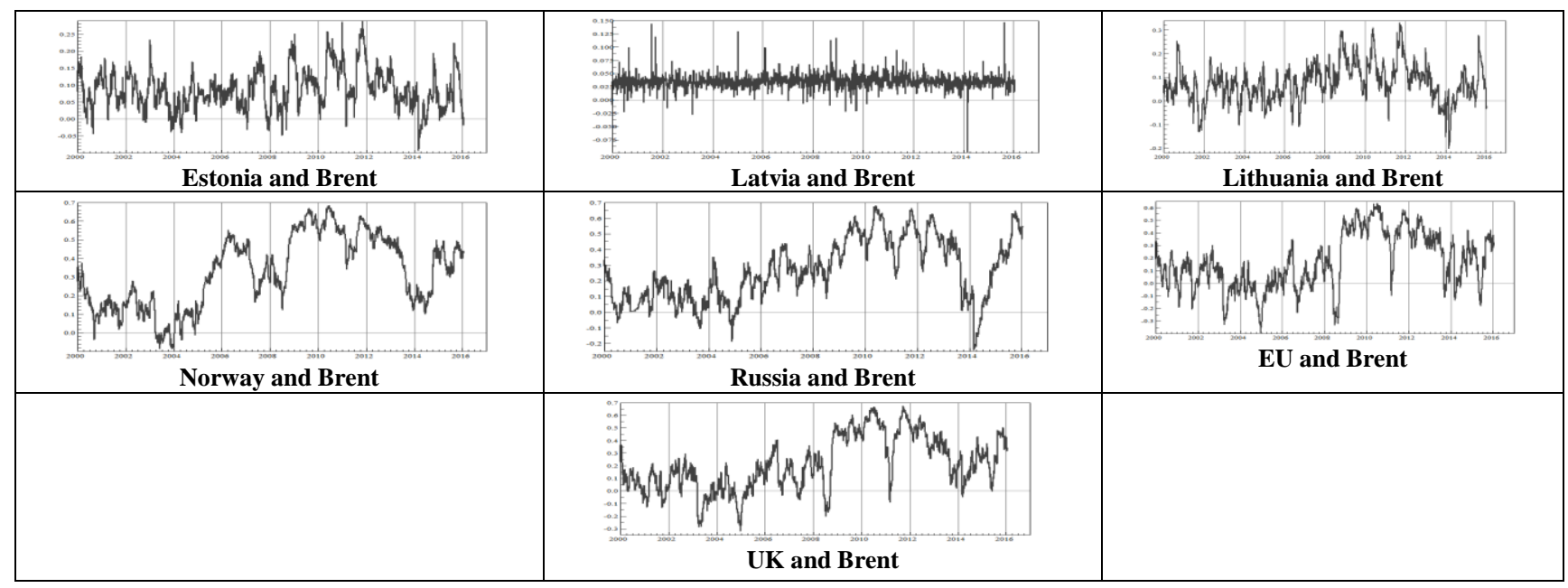

Figure 1. Dynamic Evolution between Brent and the Seven Stock Market Indices

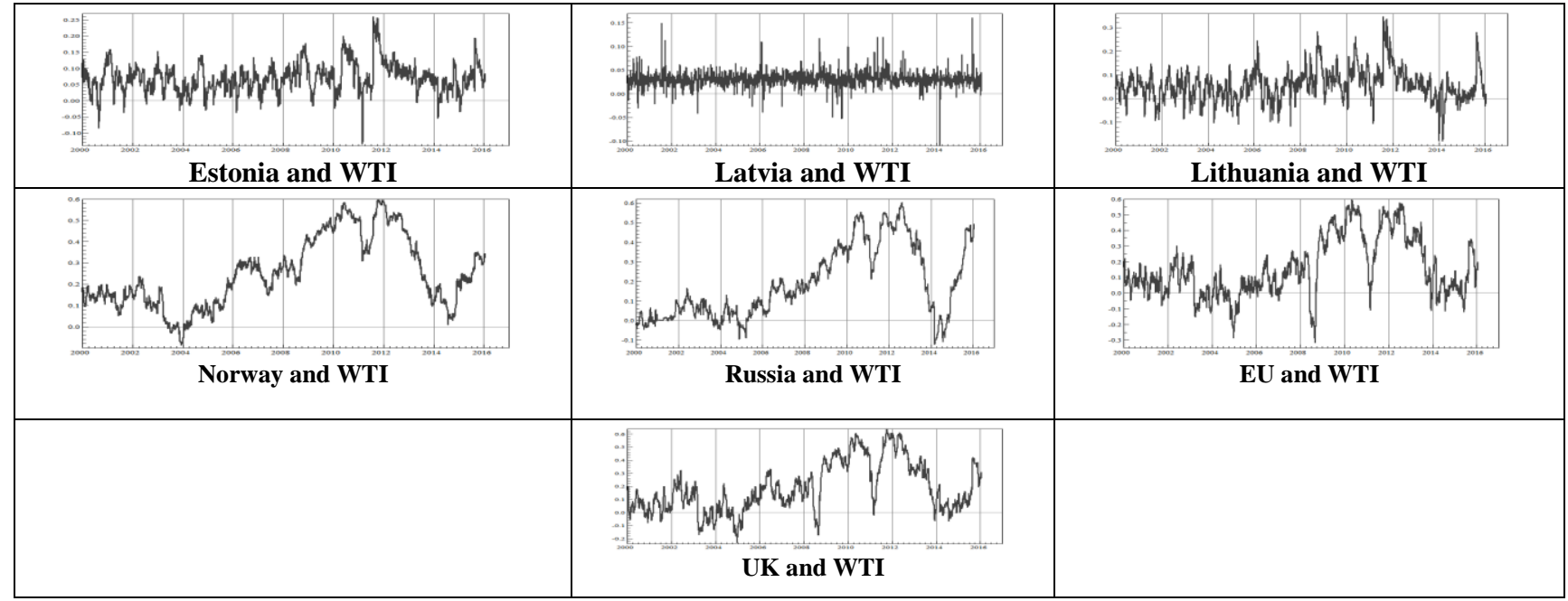

Figure 2. Dynamic Evolutions between WTI and the Seven Stock Market Indices

\section{Conclusion}

The paper empirically examines the time-varying comovement and volatility transmission between the three Baltics (Estonia, Latvia and Lithuanian) and the EU, the UK, Norway and Russia with two major oil indices (Brent and WTI) using daily data from 3 January 2000 to 18 January 2016. We selected a high frequency and relatively long period of time in order to explore the pattern and behaviour of the Baltic stock markets prior to EU accession in relation to the international oil market. The findings of the article are several. We found that the timevarying co-movement for the three Baltic stock markets is lower than that for the other countries (the EU, the UK, Norway and Russia). For the Baltic stock markets, especially for Estonia and Lithuania, the highest dynamic conditional correlation was observed during the GFC and ESDC periods, with the correlation during the latter being slightly higher. The effects of these crises were evident in Table 1, where an increase in the correlation during a crisis period can be seen to imply a fall in investors' appetites for risk, which in turn causes the market value of assets to fall. Further, the impact of the oil shock was lower in the Baltic stock markets, with the highest impact being seen for Lithuania. Interestingly, among the Baltic states, we find that Latvia is isolated from any impacts of oil shocks, which is likely due to the country not being involved in the export of oil, as well as policy makers striving for the country to become less dependent on crude oil and increasing the share of renewable energy in the total energy consumption (renewables are expected to account for $40 \%$ of the total energy consumption by 2020 , which 
is in accordance with the goals of the national target [2012]). Considering the time-varying relationship and volatility transmission between the oil-exporting and oilimporting countries, we found a slightly higher level of comovement (conditional correlation) for the oil-exporting countries, with Russia and Norway reaching the highest level of correlation during the GFC and ESDC periods. Further, for the oil-exporting countries, we observed that the co-movement switched from a negative to a positive relationship from 2005, whereas for the oil-importing countries, the co-movement changed from a negative to a positive relationship after 2008 . This finding is in line with the results obtained by Filis et al. (2011) and Bein and Aga (2016). It is also worth noting that the relationship between the stock markets and the oil price responds to both aggregate demand shock (GFC and ESDC) and supply side shock (oil supply glut). In addition, the empirical results reveal transmission volatility from the oil indices to the stock indices and vice versa. This transmission volatility is observed to be higher for the oil-exporting countries, with the highest level being seen for Norway, which reached 0.985 with Brent and 0.991 with WTI. Further, the impacts of oil shocks are also higher in oil-exporting countries, with the highest impact being seen for Russia (0.28). This finding is in line with prior studies that found oil-exporting countries to have higher volatility (Malik \& Hammoudeh, 2007; Awartani \& Maghyereh, 2013; Wang et al., 2013).
The findings of this study have implications for both policy makers and investors. Our results reveal that there exists great opportunity for international investors who would like to benefit from diversification, especially for investors who would like to invest in oil and stock markets. Such investors should consider investing in the oil sector (such as Brent and WTI) and in any of the Baltic markets. In general, all three Baltic markets have lower integration with the international crude oil market. However, Latvia seems to be isolated from intentional crude oil shocks. In addition, all three Baltics have a higher rate of return and lower volatility when compared to the other markets, which brings about additional advantages. Further, international investors can use the Baltics to hedge against risk and, at the same time, consider investing in other markets. However, our study revealed a substantial reduction in the benefits of diversification in the major oilimporting countries and oil-exporting countries. Understanding this, investors and oil companies operating in exporting countries could try to diversify their risk by investing in other countries. For example, Statoil, the Norwegian state oil company, has invested in a Scottish project to build the world's largest floating wind farm, which highlights the importance of diversifying into other sectors and other countries in order to reduce risk. In addition, policy makers within the Baltic countries should encourage international investors and oil companies to invest and thereby benefit from the lower level of risk.

\section{References}

Ahmad, N., Ahmed, R. R., Vveinhardt, J., \& Streimikiene, D. (2016). Empirical analysis of stock returns and volatility: evidence from Asian stock markets. Technological and Economic Development of Economy, 22(6), 808-829. Doi:10.3846/20294913.2016.1213204.

Aktan, B., Korsakiene, R., \& Smaliukiene, R. (2010). Time-varying volatility modelling of Baltic stock markets. Journal of Business Economics and Management, 11(3), 511-532. https://doi.org/10.3846/jbem.2010.25

Alexakis, D. P., Kenourgios, D., \& Dimitriou, D. (2016). On emerging stock market contagion: the Baltic region. Research in International Business and Finance, 36, 312-321. https://doi.org/10.1016/j.ribaf.2015.09.035

Alekneviciene, V., Alekneviciute, E.,\& Rinkeviciene, R. (2012). Portfolio size and diversification effect in Lithuanian stock exchange market. Inzinerine Ekonomika-Engineering Economics, 23(4), 338-347. https://doi.org/10.5755/j01. ee.23.4.2565

Aloui, R., Aissa, M. S. B., \& Nguyen, D. K. (2011). Global financial crisis, extreme interdependences, and contagion effects: the role of economic structure?. Journal of Banking and Finance, 35, 130-141. https://doi.org/10.1016/ j.jbankfin.2010.07.021

Antonakakis, N., \& Filis, G. (2013). Oil prices and stock market correlation: A time-varying approach. International Journal of Energy and Statistics, 1, 17-29. https://doi.org/10.1142/S2335680413500026

Antoniou, A., Koutmos, G., \& Percli, A. (2005). Index futures and positive feedback trading: evidence from major stock Exchanges. Journal of Empirical Finance, 12(2), 219-238. https://doi.org/10.1016/j.jempfin.2003.11.003

Arouri, M., Lahiani, A., \& Nguyen, D. K. (2011). Return and volatility transmission between world oil prices and stock markets of the GCC countries. Economic Modelling, 28(4), 1815-1825. https://doi.org/10.1016/j.econmod. 2011.03.012

Arouri, M., Dinh, T.H., \& Nguyen, D.K., (2010). Time-varying predictability in crude oil markets: the case of GCC countries. Energy Policy, 38 (8), 4371-4380. https://doi.org/10.1016/j.enpol.2010.03.065

Avdulaj, K., \& Barunik, J. (2013). Are benefits from oil-stocks diversification gone? New evidence from dynamic copulas and high-frequency data. Energy Economics, 51(C), 31-44. https://doi.org/10.2139/ssrn.2297226

Awartani, B., \& Maghyereh, A. I. (2013). Dynamic spillovers between oil and stock markets in the Gulf Cooperation Council countries. Energy Economics, 36, 28-42. https://doi.org/10.1016/j.eneco.2012.11.024 
Murad A. Bein. Time-Varying Co-Movement and Volatility Transmission between the Oil Price and Stock Markets in...

Babalos, V., Balcilar, M. B., Loate, B. T., \& Chisoro, S. (2016). Did Baltic stock markets offer diversification benefits during the recent financial turmoil? Novel evidence from a nonparametric causality-in-quantiles test. Empirica. doi 10.1007/s10663-016-9344-4.

Backus, K. D., \& Crucini, M. J. (2000). Oil prices and the terms of trade. Journal of International Economics, 50(1), 185-213. https://doi.org/10.1016/S0022-1996(98)00064-6

Basher, S. A., \& Sadorsky, P. (2006). Oil price risk and emerging stock markets. Global Finance Journal, 17(2), $224-251$. https://doi.org/10.1016/j.gfj.2006.04.001

Bein, A. M., \& Tuna, G. (2016). Comparing spillover effects among emerging markets with a higher (lower) share of commodity exports: evidence from the two major crises. Economic Computation and Economic Cybernetics Studies and Research, 3(50), 265-284.

Bein, A. M., \& Aga, M. (2016). On the linkage between the international crude oil price and stock markets: evidence from the Nordic and other European oil importing and oil exporting countries. Romanian Journal of Economic Forecasting, 19(4), 115-134.

Bjornland, H. C. (2009). Oil price shocks and stock market booms in an oil-exporting country. Scottish Journal of Political Economy, 56(2), 232-254. https://doi.org/10.1111/j.1467-9485.2009.00482.x

Bloomberg, (2017). Oil, Gas and Consumable Fuels. Overview of Ab Orlen Lietuva. Retrieved from http://www.bloomberg.com/research/stocks/private/snapshot.asp?privcapId=1039514.

Bouri, E. (2015). Oil volatility shocks and the stock markets of oil-importing MENA economies: a tale from the financial crisis. Energy Economics, 51(C), 590-598. https://doi.org/10.1016/j.eneco.2015.09.002

Brannas, K., \& Soultanaeva, A. (2011). Influence of news from Moscow and New York on returns and risks of Baltic States' stock markets. Baltic Journal of Economics, 11(1), 109-124. DOI:10.1080/1406099X.2011.10840493.

Brannas, K., De Gooijer, J. G., Lonnbark, C., \& Soultanaeva, A. (2012). Simultaneity and asymmetry of returns and volatilities: the emerging Baltic States' stock exchanges. Studies in Nonlinear Dynamics \& Econometrics, $16,1-24$.

Chiang, T. C., Jeon, B. N., \& Li, H. (2007). Dynamic correlation analysis of financial contagion: evidence from Asian markets. Journal of International Money and Finance, 26(7), 1206-1228. https://doi.org/10.1016/j.jimonfin. 2007.06.005

Cong, R. G., Wei, Y. M., Jiao, J. L., \& Fan, Y. (2008). Relationships between oil price shocks and stock market: an empirical analysis from China. Energy Policy, 36, 3544-3553. https://doi.org/10.1016/j.enpol.2008.06.006

Chen, S. S. (2009). Do higher oil prices push the stock market into bear territory?. Energy Economics, 32(2), $490-495$. https://doi.org/10.1016/j.eneco.2009.08.018

Dajcman, S., \& Kavkler, A. (2011). A comparative DCC-GARCH and rolling wavelet correlation analysis of interdependence between the Slovenian and European stock markets. Economic Computation and Economic Cybernetics Studies and Research, 45(4), 99-118.

Deltuvaite, V. (2016). Cross-border contagion risk transmission through stock markets channel: the case of the Baltic countries. Eurasian Studies in Business and Economics, 43-54. doi: 10.1007/978-3-319-39919-5_4

Deltuvaite, V. (2016). Investigation of stock markets integration in the Baltic countries. Economics and Business, 28(1), 38-44. doi:10.1515/eb-2016-0006.

Dhaoui, A., \& Khraief, N. (2014). Empirical linkage between oil price and stock market returns and volatility: evidence from international developed markets. Discussion Paper.

Dubinskas, P. \& Stunguriene, S. (2010). Alterations in the financial markets of the Baltic countries and Russia in the period of economic downturn. Technological and Economic Development of Economy, 16(3), 502-515. https://doi.org/10.3846/tede.2010.31

European Central Bank (2012). Agenda 2013: the next steps in completing EMU. Available from https://www.ecb.europa. $\mathrm{eu} / \mathrm{press} / \mathrm{key} / \mathrm{date} / 2012 \mathrm{html} / \mathrm{sp} 121219 . \mathrm{en} . \mathrm{html}$.

Engle, R. F. (2002). Dynamic conditional correlation - a simple class of multivariate GARCH models. Journal of Business and Economic Statistics,20(3), 339-350. https://doi.org/10.1198/073500102288618487

Energy Regulators Regional Association (2013). Baltic Energy Market Profile. Estonian Competition Authority (ECA), Public Utilities Commission of Latvia (PUC), National Control Commission for Prices and Energy of Lithuania

(NCC) on the occasion of the 12th ERRA Energy Investment and Regulation Conference, in Tallinn, Estonia.

Federal Reserve Board of St. Louis. (2009). The Financial Crisis: A Timeline of Events and Policy Actions. Available from https://www.stlouisfed.org/financial-crisis/full-timeline .

Filis, G., Degiannakis, S., \& Floros, C. (2011). Dynamic correlation between stock market and oil prices: the case of oilimporting and oil-exporting countries. International Review Financial Analysis, 20(3),152-164. https://doi.org/10.1016/j.irfa.2011.02.014 
Farchy, J., \& Wigglesworth, R. (2016). Oil back above \$50 as OPEC agrees supply cut. Financial Times, Available from https://www.ft.com/content/98f3bf56-b6e6-11e6- ba85-95d1533d9a62.

Fattouh, B. (2011). An Anatomy of the Crude Oil Pricing System. The Oxford Institute for Energy Studies. Working paper no 40.

Forbes, K., \& Rigobon, R. (2002). No contagion, only interdependence: measuring stock market co- movements. Journal of Finance, 57(5), 2223-2262. https://doi.org/10.1111/0022-1082.00494

Guesmi, K., \& Fattoum, S. (2014). Return and volatility transmission between oil prices and oil-exporting and oilimporting countries. Economic Modelling, 38,305-310. https://doi.org/10.1016/j.econmod.2014.01.022

Jones, C. M., \& Kaul, G. (1996). Oil and the stock markets. Journal of Finance, 51(2): 463-491. doi:10.1111/j.15406261.1996.tb02691.x.

Harkmann, K. (2014). Stock market contagion from Western European to Central and Eastern Europe during the crisis years 2008-2012. Eastern European Economics, 52(3), 55-65. https://doi.org/10.2753/EEE0012-8775520303

Ghosh, S., \& Kanjilal, K. (2014). Co-movement of international crude oil price and Indian stock market: evidence from nonlinear cointegration tests. Energy Economics, 53, 111-117. doi:10.1016/j.eneco.2014.11.002.

Kang, W., Ratti, R. A., \& Yoon, K. H. (2015). The impact of oil price shocks on the stock market return and volatility relationship. Journal of International Financial Markets Institutions and Money, 34, 41-54. https://doi.org/10.1016/j.intfin.2014.11.002

Kiran, B. (2011). Fractional cointegration relationship between oil prices and stock markets: an empirical analysis from G7 countries. Prague Economic Papers, 20(2), 177-189. https://doi.org/10.18267/j.pep.395

Kaminsky, L. G., \& Reinhardt, C. (1999). The twin crises: the causes of banking and balance-of-payment problems, American Economic Review, 89(3), 473-500. https://doi.org/10.1257/aer.89.3.473

Kose, M. A., Prasad, E. S., \& Terrones, M. E. (2006). How do trade and financial integration affect the relationship between growth and volatility?. Journal of International Economics, 69(1), 176-202. https://doi.org/10. 1016/j.jinteco.2005.05.009

Krjukov.A., \& Rajavee, A. (2016). VKG koondab 500 inimest. Available from http://www.err.ee/552527/vkg-koondab500- inimest

Levine, R. (1997). Financial development and economic growth: views and agenda. Journal of Economic Literature. 35 , 688-726.

Levisauskaite, K., Alekneviciene, V., \& Rinkeviciene, R. (2014). Comovements of financial markets in the EU countries. Inzinerine Ekonomika-Engineering Economics, 25(3). https://doi.org/10.5755/j01.ee.25.3.5079

Liuhto, K., \& Jumpponen, J. (2002). The internationalisation boom of Russian corporations. Research Report N:o 135, 2002. Lappeenranta University of Technology. Department of Industrial Engineering and Management. Available from http://www.compiler.fi/idankaupan/tutkimukset/LTKK12.html.

Baltija., L. (2011). Lukoil Baltija uab is the sole official representative of the manufacturers lukoil (Russia) and addinol (Germany) in Lithuania. Available from http://www.lukoil.lt/en/products_services/oils_and_lubricants.

Miller, J. I., \& Ratti, R. A. (2009). Crude oil and stock markets: stability, instability, and bubbles. Energy Economics, 31(4), 559-568. https://doi.org/10.1016/j.eneco.2009.01.009

Malik, S., \& Hammoudeh, S. (2007). Shock and volatility transmission in the oil, US and Gulf equity markets. International Review of Economics and Finance, 17, 357-368. https://doi.org/10.1016/j.iref.2005.05.005

Maneschiold, P. O. (2006). Integration between the Baltic and international stock markets. Emerging Markets Finance and Trade, 42(6), 25-45. https://doi.org/10.2753/REE1540-496X420602

Masood, O., Bellalah, M., Chaudhary, S., Mansour, W., \& Teulon, F. (2010). Cointegration of Baltic stock markets in the financial tsunami: empirical evidence. International Journal of Business, 15, 119-132.

Masih, R., Peters, S., \& de Mello, L. (2011). Oil price volatility and stock price fluctuations in an emerging market: evidence from South Korea. Energy Economics, 33(5), 975-986. https://doi.org/10.1016/j.eneco.2011.03.015

Moya., E. (2009). Investors' fears grow over Greek economy. Available from https://www.theguardian.com/business/ 2009/nov/ 30/greece-economy-budget-deficit-fears.

National Traget. (2012). Europe 2020 in Latvia. Europe 2020 targets - State of play. Available from http://ec.europa.eu/europe2020/europe-2020-in-your-country/latvija/progress-towards-2020-targets/index_en.htm.

Nielsson, U. (2007). Interdependence of Nordic and Baltic stock markets. Baltic Journal of Economics, 6, 9-27. https://doi.org/10.1080/1406099X.2007.10840434

Nikkinen, J., Piljak, V., \& Aijo, J. (2012). Baltic stock markets and the financial crisis of 2008-2009. Research in International Business and Finance, 26(3), 398-409. https://doi.org/10.1016/j.ribaf.2012.03.003

Park, J., \& Ratti, R. A. (2008). Oil price shocks and stock markets in the US and 13 European countries. Energy Economics 30, 2587-2608. https://doi.org/10.1016/j.eneco.2008.04.003 
Murad A. Bein. Time-Varying Co-Movement and Volatility Transmission between the Oil Price and Stock Markets in...

Pilinkus, D., \& Boguslauskas, V. (2015). The short-run relationship between stock market prices and macroeconomic variables in Lithuania: an application of the impulse response function. Inzinerine Ekonomika-Engineering Economics, 65(5).

Reboredo, J. C. (2010). Nonlinear effects of oil shocks on stock returns: a Markov-switching approach. Applied Economics, 42(29), 3735-3744. https://doi.org/10.1080/00036840802314606

Sadorsky, P. 2012. Correlations and volatility spillovers between oil prices and the stock prices of clean energy and technology companies. Energy Economics, 34, 248-255. https://doi.org/10.1016/j.eneco.2011.03.006

Sadorsky, P. (1999). Oil price shocks and stock market activity. Energy Economics, 21(5), $449-469$. https://doi.org/10.1016/S0140-9883(99)00020-1

Soultanaeva, A. (2008). The impact of political news on the Baltic state stock markets. Umeå Economic Studies, 735, 1-21.

Stasiukonyte, J., \& Vasiliauskaite, A. (2008). Nature of Baltic and Scandinavian stock markets integration process. Economics \& Management, 196-204.

Syllignakis, M. N., \& Kouretas, G. P. (2011). Dynamic correlation analysis of financial contagion: evidence from the Central and Eastern European markets. International Review of Economics and Finance, 20,717-732. https://doi.org/10.1016/j.iref.2011.01.006

Vahtla, A. (2017). Eesti Energia: \$2.1 billion oil shale project secures funding. Available from http://news.err.ee/584500/ eesti- energia-2-1-billion-oil-shale-project-secures-funding.

Vopak E.O.S. company profile available from http://www.vopakeos.com/about-vopak-e-o-s/?lang=en.

Vveinhardt, J. Streimikiene, D. Ahmed, R. R. Ahmed, R., \& Rehman, A. (2016). Mean reversion: an investigation from Karachi stock exchange sectors. Technological and Economic Development of Economy, 22(4), 493-511.

Wang, Y., Wu, C., \& Yang, L. (2013). Oil price shocks and stock market activities: evidence from oil-importing and oilexporting countries. Journal of Comparative Economics, 41(4), 1220-1239. https://doi.org/10.1016/j.jce.2012.12.004

Workman, D. (2017) Crude Oil Exports by Country. Available from internet: http://www.worldstopexports.com/worldstop-oil-exports-country.

Zhu, H. M., Li, R., \& Li, S. (2014). Modeling dynamic dependence between crude oil prices and Asia-Pacific stock market Returns. International Review Economics Finance, 29, 208-222. https://doi.org/10.1016/j.iref.2013.05.015

The article has been reviewed.

Received in January, 2017; accepted in December, 2017. 